\title{
Entrepreneurship and strategic thinking in business ecosystems
}

\author{
Shaker A. Zahra ${ }^{a, *}$, Satish Nambisan ${ }^{\text {b }}$ \\ ${ }^{a}$ Gary S. Holmes Center for Entrepreneurial Studies, Carlson School of Management, \\ University of Minnesota, 321 Nineteenth Avenue South, Minneapolis, MN 55455, U.S.A. \\ ${ }^{\mathrm{b}}$ Sheldon B. Lubar School of Business, College of Engineering \& Applied Sciences, \\ University of Wisconsin-Milwaukee, P.O. Box 742, Milwaukee, WI 53201, U.S.A.
}

\section{KEYWORDS}

Business ecosystem; Entrepreneurship; Strategic thinking; Innovation

\begin{abstract}
Success in business ecosystems that include well-established companies and new ventures requires collaboration and competition, a task that demands strategic thinking to leverage a firm's resources and capabilities. Strategic thinking and the entrepreneurial activities in an ecosystem influence one another in a cycle that perpetuates and even sparks innovation. These interactions vary significantly across four types of business ecosystems-Orchestra, Creative Bazaar, Jam Central, and MOD Station-and determine the success and failures of new ventures and established companies. The nature and effect of the dynamic interactions in a business ecosystem can have profound implications for organizational success.

(C) 2011 Kelley School of Business, Indiana University. All rights reserved.
\end{abstract}

\section{Competing in business ecosystems}

Once defined by time, space, and resource bundles, competition is increasingly determined by the quality of strategic thinking about the firm's opportunities, challenges, core competences, capabilities, and competitive arena. Executives have to navigate a constantly changing competitive arena that is no longer defined by physical or even digital dimensions; it encompasses the global networks and ecosystems within which the firm competes (Zahra \& Nambisan, 2011). These networks provide the firm

\footnotetext{
* Corresponding author.

E-mail addresses: zahra004@umn.edu (S.A. Zahra), nambisan@uwm.edu (S. Nambisan).
}

with resources, alliance partners, and important information about market conditions. Referred to as 'business ecosystems,' the networks are the product of a long and evolutionary process that defines relationships among industry players.

Creating, shaping, navigating, and exploiting business ecosystems requires entrepreneurial insight, coupled with strategic thinking. This thinking becomes evident in the novelty and speed of strategic actions, as well as the creativity of resource deployment and use. It also manifests itself in the creation of a new organization or venture that is capable of adapting and transforming itself as the forces of competition change. Such an organization is capable of simultaneously creating and discovering opportunities while creatively and profitably exploiting other opportunities. Competing in ecosystems requires-in 
fact, demands-the synchronization of strategic thinking and entrepreneurship, a process that further creates new knowledge supporting entrepreneurial activities and strategic thinking (lansiti \& Levien, 2004; Nambisan \& Sawhney, 2007a).

Herein, we explore the dynamic interplay between entrepreneurship and strategic thinking in different types of business ecosystems and how that interplay affects the ways companies compete. These ecosystems are widely considered the hotbeds of industry knowledge: the knowledge that underlies competitive moves, and knowledge about the customers and competition. A business ecosystem is a group of companies-and other entities including individuals, too, perhaps - that interacts and shares a set of dependencies as it produces the goods, technologies, and services customers need. These interactions reflect and reinforce these companies' co-specialization in different economic activities, and are often orchestrated and shaped by a central player that provides the incentives for other companies to co-evolve, align their goals and activities, and further bond themselves to one another (Moore, 1993, 1996; Nambisan \& Sawhney, 2007a).

\section{Thinking strategically}

A typical business ecosystem usually houses both well-established companies and new ventures. Some ventures are corporate-sponsored, while others are launched by independent entrepreneurs. Established companies and new ventures play different but often complementary roles that position them to exploit particular areas of the ecosystems (Livingston, 2007), a process that further promotes productive co-specialization which in turn enriches the variety of entrepreneurial activities in the ecosystems. Along with their diverse entrepreneurial activities, the interactions of these companiesboth established and new-determine the speed of the ecosystem's evolution to keep it vibrant, offering plenty of opportunities for its members. Established companies and new ventures need to engage themselves in thinking strategically about the ecosystem in which they exist, their place within it, and how to develop and cultivate relationships with its other members. To be fruitful, strategic thinking has to address these fundamental issues while overcoming organizational and other barriers to a firm's evolution.

Strategic thinking transcends time, space, and resources to offer innovative solutions to complicated and perplexing issues a company faces in its competitive arena (Hamel \& Prahalad, 1994; Mintzberg, 1987). As such, strategic thinking has several interrelated qualities, including a long-term orientation, a systemic and integrative approach toward problem solving, and creativity (Abraham, 2005; Liedtka, 1998). Strategic thinking focuses on visualizing the future before it happens, a process that entails building and considering different scenarios. These scenarios represent the agglomeration of different visions and forces that give meaning to an overall set of assumptions and predictions about future states. As such, strategic thinking often requires reconciling competing hypotheses about the future and integration of divergent views into a coherent whole. This integration requires creativity and intelligence. Strategic thinking is also systemic in that it builds on the linkages among different components that form a vision for the future. Transforming this vision into reality is likely to be a longterm process, where organizational resources are dedicated to making this transformation possible. Because definitions of the arena, competition, and competitive tools are new, strategic thinking is often associated with radical and revolutionary transitions in the life of industries and companies (Chussil, 2005; Hamel, 1996; Hamel \& Prahalad, 1994).

Strategic thinking requires creativity, as well as foresight and insight. Foresight means shadowing the future; that is, foreseeing its shape before it materializes. Insight revolves around uncovering ways that give birth and meaning to the future. It embodies creativity, inventiveness, and proactiveness in changing the competitive arena and inducing new dynamics. It often entails revising the boundaries and complexion of the competitive arena, as well as challenging and sometimes revising the assumptions that underlie market forces. Insight also creates new competitive spaces by reconfiguring or altering the links that exist in a firm's ecosystem. Reconceptualizing the domain, content, and relationships among its key components can give the firm an opportunity to compete in an arena where it sets its own rules of the game (Zahra \& Nambisan, 2011).

Foresight and insight are bounded by imagination, not simply by resources or geography. Entrepreneurs understand that foresight and insight are based upon, and shaped by, the firm's ecosystem. These entrepreneurs know that their companies depend on broad settings and diverse webs of relationships for survival. In turn, survival requires addressing the limitations of that ecosystem, working around its complexity and constraints, and learning how to turn these challenges into focused and purposeful actions that create value. Being able to comprehend and respond to these challenges is the crux of strategic thinking. 
In today's organizations, strategic thinking is not the sole responsibility of senior managers. Some of the most creative ideas that stimulate strategic thinking come from middle and lower level managers, as well as employees who interact with customers, suppliers, and other stakeholders. Employees who are steeped in the knowledge of their company's operations are well positioned to come up with some of the more interesting strategic moves that have promise to transform the company's business and change the dynamics of competition (Hamel, 1996). Employees often develop their own knowledge networks via which they share, discuss, and evaluate ideas for products, above and beyond the company's evolution. They also keep in contact with others who belong to professional and personal friendship networks, another valuable source of ideas for strategic thinking. Learning to stimulate and capture these diverse ideas from managers and employees through the organization can enrich the menu from which senior executives harness ideas for strategic change, especially when they unleash the firm's entrepreneurial capabilities and potential.

\subsection{Strategic thinking in new ventures}

Ecosystems host independent and corporatesponsored new ventures, companies 6 years or younger. While these two venture groups have several things in common, they usually pursue different goals, using dissimilar bundles of skills and resources (Zahra, 2007). They occupy different niches within the ecosystem, exposing them to unique strategic challenges. They also have different time frames, making their resource allocation decisions diverse. It is worthwhile, therefore, to consider these two groups of new ventures separately.

\subsubsection{Independent new ventures}

New ventures working on the fringes of their respective industries are able to develop in ways that allow them to grow from niche players to value dominators, or even industry leaders-also known as keystones. These companies have shown considerable adeptness in restructuring their organizations and reconfiguring their business models, which made it possible for them to develop and succeed. They often have advantages over established companies in terms of learning, sharing knowledge, and rapidly revising their strategic moves. With their founders at the helm, these ventures can streamline their operations, unfettered by sunk costs, prior relationships, or historical forces.

Many entrepreneurs rely on intuition when making decisions regarding their new companies. It has been suggested that one consequence of this is that new ventures do not always use formal planning, as entrepreneurs tend to be ad hoc in their decision making. These entrepreneurs are prone to overconfidence, optimism, generalizing from small numbers, and rigidity (Busenitz \& Barney, 1997). Overconfidence means entrepreneurs are likely to believe in their ideas, creations, and firms more than is warranted by facts. Optimism means that entrepreneurs tend to see positive trends even in bad or bleak news (Dushnitsky, 2010); as a result, entrepreneurs might set higher growth and profit goals than is reasonable given industry conditions. This optimism is reinforced by another tendency that entrepreneurs have: to generalize beyond what the data and facts indicate, often using bits of information and anecdotes to support their mistaken beliefs. Optimism and overconfidence combine to explain why some entrepreneurs persist, even when all indications show their ventures are failing. Rigidity plays an important role, too. Entrepreneurs are unlikely to alter their views, even when initial feedback suggests the need for change and flexibility. This rigidity can be deadly if not countered with a thorough grounding in reality.

Entrepreneurs often experience a number of challenges as they engage in strategic thinking. Industry boundaries are not clearly delineated; this happens over time as companies lay claim to various parts of the market, differentiating themselves from one another. When creating new types of organizations - for example, a new venture in an industry that is unknown or does not even exist-comparisons with other ventures can be misleading or even deadly. Data simply do not exist about other companies that might enter the industry, where and when they might enter, and how well they are likely to compete. Entrepreneurs are also busy people and work under severe resource constraints. That limits the time available for thinking about and playing out various potential scenarios.

While countless entrepreneurs in the high-tech industry have strong technical training and experience, just as many tend to ignore the organizational side of competition; that is, how organizations are built, decisions are made, resources are allocated, and so forth. They also fail to capitalize on their connections in and outside the industry, to seek the advice and help they need to build the scale and scope of operations for success. Part of these founders' strategic challenge is to connect their ventures to the broader ecosystem, a process that requires understanding the dynamics that govern relationships within that system and the function of entrepreneurial activities in this regard. The nature of these entrepreneurial activities is determined by the role a new venture aims to play in its ecosystem. While many are content with being niche players, 
others focus on being physical or value dominators, or even evolve into the central node that connects participants and develops rules of engagementthat is, being a keystone company.

\subsubsection{Corporate-sponsored new ventures}

Many of the new ventures that populate an ecosystem are created by well-established companies. These corporate-sponsored ventures are launched to probe or exploit opportunities within the ecosystem, especially those parts experiencing technological change coupled with high growth (Andrew, Birkinshaw, Morrison, \& Van Basten Batenburg, 2003; Keil, McGrath, \& Tukiainen, 2009). The domain of these corporate ventures is usually established by their corporate parents, who often also control operations. Corporate ventures typically pursue higher rates of growth and profitability than their independent counterparts. They also benefit from the resources, skills, and connections of their parent corporations.

Corporate ventures face the dual challenge of building credibility with their parents and establishing market legitimacy. Though better funded than independent ventures, these ventures might be constrained by the ambitious goals their parents establish for them and the controls placed on them. While corporations grant their ventures varying degrees of autonomy, these ventures' decisions are subject to major review by corporate planners and staff. Corporate venture managers, therefore, have to work within the confines of their official mandates, budgets, and timetables. Strategic thinking centers on garnering and retaining the corporate parent's support, yet at the same time uncovering new ways of doing things and developing an understanding of successful operational recipes. Venture managers also need to consider ways they may effectively grow the organization and manage its evolution. Winning the support of the corporate parent management and staff is an ongoing, consuming strategic challenge (Table 1).

\section{The dynamic interplay in an ecosystem}

Dynamic interplay occurs between strategic thinking and entrepreneurship in a business ecosystem. Strategic thinking requires attention to, and consideration of, the linkages that exist among members of the ecosystem. These relationships develop because of specialization in different skill areas, historical ties among companies, and personal relationships among people working in different parts of the ecosystem. Entrepreneurs appreciate that long-term success hinges on understanding, managing, and effectively and creatively exploiting these linkages. Therefore, they work on establishing and cultivating these linkages, recognizing their crucial importance in transforming the ecosystem by changing the mix of resources needed to operate in that ecosystem or introducing new business models that redefine how companies within their ecosystem behave. Entrepreneurs also focus on systematically reshaping the ecosystem to their advantage, rather than simply managing existing relationships. As with biological and ecological ecosystems, business ecosystems are susceptible to change, adaptation, and evolution. However, the outcomes of these processes are hard to predict and take time to materialize.

As seen in Figure 1, entrepreneurship is a major source of frames of reference and mental models that give rise to new strategic initiatives (Isenberg, 2010). Entrepreneurship plays three interrelated roles: a source of strategic initiatives; a lever in positioning the firm; and a set of activities that actualize firms' strategic moves, thereby creating value. This ongoing cycle in turn highlights the importance of learning, another source of knowledge that defines the different types of entrepreneurial opportunities of the firm.

To illustrate the dynamic link between entrepreneurship and strategic thinking, we consider four different models of ecosystems that differ in terms of the nature of innovation space they inhabit and the nature of governance. These models are aptly termed: Orchestra, Creative Bazaar, Jam Central, and MOD Station (Nambisan \& Sawhney, 2007a). Table 2 provides an overview of various entrepreneurial activities and corresponding challenges related to strategic thinking that established companies and new ventures face in each of these four ecosystems.

\subsection{The Orchestra Model}

This ecosystem model typically involves a group of firms coming together to exploit a market opportunity based on an explicit innovation architecture/ platform that is defined and shaped by a dominant firm, or the keystone player. This ecosystem closely resembles the organization and structure of a typical symphony orchestra: a conductor holding sway with her wand, directing a group of musicians, each a specialist in a specific musical instrument. The dominant firm provides strong network leadership by envisioning and clarifying the innovation architecture which offers a basis for structuring the activities of the individual players within the ecosystem. For example, both Intel and Microsoft enjoy the benefits of being keystone firms in their Orchestra Model ecosystems. Typically, new ventures 
Table 1. Strategic thinking in new ventures and established companies

\begin{tabular}{|c|c|c|c|}
\hline Variable & Independent Ventures & Corporate Ventures & Established Companies \\
\hline Domain & $\begin{array}{l}\text { Negotiated, defined based } \\
\text { on market success }\end{array}$ & $\begin{array}{l}\text { Negotiated, an outcome } \\
\text { of negotiations with } \\
\text { corporate staff }\end{array}$ & $\begin{array}{l}\text { Clearer and well established } \\
\text { but revised based on } \\
\text { manager's aspirations, } \\
\text { resources, and the firm's } \\
\text { opportunity set }\end{array}$ \\
\hline $\begin{array}{l}\text { Key Role in } \\
\text { Ecosystem }\end{array}$ & $\begin{array}{l}\text { Niche } \\
\text { Dominator }\end{array}$ & $\begin{array}{l}\text { Dominator } \\
\text { Niche }\end{array}$ & $\begin{array}{l}\text { Keystone } \\
\text { Dominator }\end{array}$ \\
\hline $\begin{array}{l}\text { Key Node } \\
\text { in } \\
\text { Strategic Thinking }\end{array}$ & Entrepreneurs & $\begin{array}{l}\text { Corporate Managers } \\
\text { Corporate Staff } \\
\text { Venture Managers }\end{array}$ & $\begin{array}{l}\text { Top Management } \\
\text { Middle and Lower } \\
\text { Managers \& Employees }\end{array}$ \\
\hline $\begin{array}{l}\text { Strategic } \\
\text { Thinking }\end{array}$ & $\begin{array}{l}\text { Intuitive } \\
\text { Improvisational } \\
\text { Ad hoc } \\
\text { Informal }\end{array}$ & $\begin{array}{l}\text { Analytical } \\
\text { Numbers driven }\end{array}$ & $\begin{array}{l}\text { Analytical } \\
\text { Formalized }\end{array}$ \\
\hline $\begin{array}{l}\text { Factors that } \\
\text { Facilitate } \\
\text { Strategic Thinking }\end{array}$ & $\begin{array}{l}\text { Owner at the center } \\
\text { Learning advantages } \\
\text { of newness }\end{array}$ & $\begin{array}{l}\text { Corporate support } \\
\text { Well trained venture } \\
\text { staff }\end{array}$ & $\begin{array}{l}\text { Formalized process } \\
\text { Grounded in competitive } \\
\text { analysis }\end{array}$ \\
\hline $\begin{array}{l}\text { Barriers to } \\
\text { Strategic Thinking }\end{array}$ & $\begin{array}{l}\text { Entrepreneur's } \\
\text { cognitive limitations } \\
\text { Industry is ill defined } \\
\text { Busy schedules }\end{array}$ & $\begin{array}{l}\text { Fixed mandates } \\
\text { Established budgets } \\
\text { Corporate control }\end{array}$ & $\begin{array}{l}\text { Competence trap } \\
\text { Focusing on companies } \\
\text { that have the same } \\
\text { organizational form } \\
\text { Paralysis by analysis }\end{array}$ \\
\hline
\end{tabular}

Figure 1. The dynamic link between entrepreneurship and strategic thinking in business ecosystems

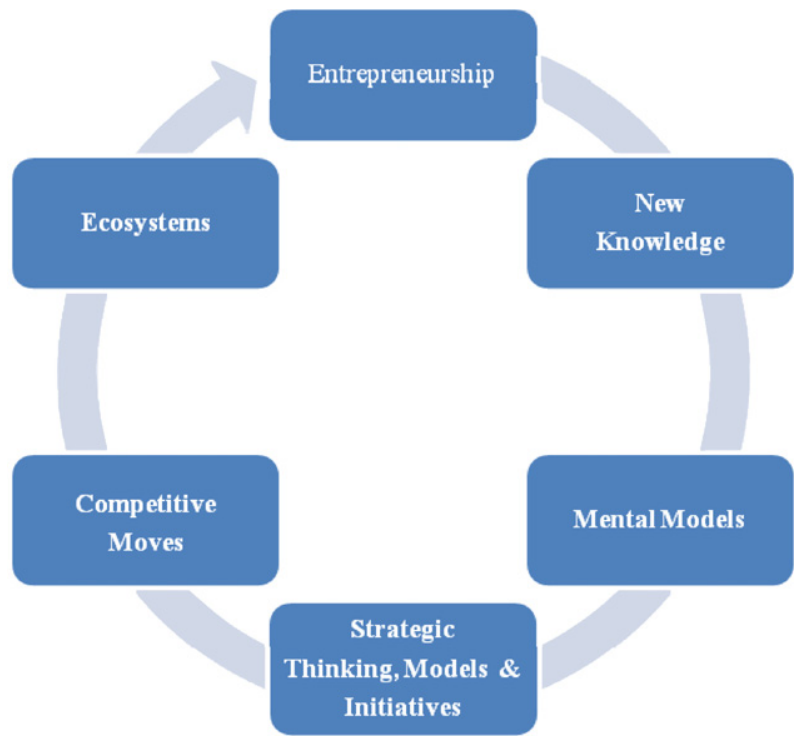


Table 2. Strategic thinking \& entrepreneurship in four ecosystems

\begin{tabular}{|c|c|c|c|}
\hline \multirow{2}{*}{$\begin{array}{l}\text { Type of } \\
\text { Ecosystem }\end{array}$} & \multicolumn{3}{|c|}{ Strategic Thinking \& Entrepreneurship By } \\
\hline & Established Companies & Corporate Ventures & Independent Ventures \\
\hline Orchestra & $\begin{array}{l}\text { (a) Rethink ecosystem focus \& } \\
\text { boundaries to ensure its } \\
\text { external market relevance } \\
\text { (b) Adopt an integrative, long- } \\
\text { term perspective and } \\
\text { incorporate partners' goals/ } \\
\text { interests at all levels of } \\
\text { internal decision making }\end{array}$ & $\begin{array}{l}\text { (a) Explore radically new } \\
\text { technological fields } \\
\text { (b) Connect supplier and } \\
\text { buyer groups, and link } \\
\text { these groups to the } \\
\text { parent corporation }\end{array}$ & $\begin{array}{l}\text { (a) Pursue new value-adding } \\
\text { knowledge combinations } \\
\text { related to the innovation } \\
\text { platform } \\
\text { (b) Identify and exploit non- } \\
\text { obvious connections among } \\
\text { internal knowledge assets } \\
\text { and those of other partners }\end{array}$ \\
\hline $\begin{array}{l}\text { Creative } \\
\text { Bazaar }\end{array}$ & $\begin{array}{l}\text { (a) Rethink the core assets and } \\
\text { the markets to be served, } \\
\text { and adopt a bold approach } \\
\text { toward external innovation } \\
\text { sourcing } \\
\text { (b) Develop and maintain an } \\
\text { 'open' commercialization } \\
\text { infrastructure - one that } \\
\text { allows partners to 'plug and } \\
\text { play' their innovative ideas }\end{array}$ & $\begin{array}{l}\text { (a) Expedite and facilitate } \\
\text { commercialization } \\
\text { activities without being } \\
\text { trapped in corporate } \\
\text { routines and politics } \\
\text { (b) Retain the loyalty and } \\
\text { support of ecosystem } \\
\text { partners and ensure their } \\
\text { continued motivation }\end{array}$ & $\begin{array}{l}\text { (a) Move away from the 'founder } \\
\text { at the center' model to one } \\
\text { that shares control over idea } \\
\text { commercialization with } \\
\text { established companies } \\
\text { (b) Redefine R\&D areas/ } \\
\text { investments to position the } \\
\text { new venture as the } \\
\text { 'preferred front-end of } \\
\text { innovation' of an established } \\
\text { company }\end{array}$ \\
\hline $\begin{array}{l}\text { Jam } \\
\text { Central }\end{array}$ & $\begin{array}{l}\text { (a) Think beyond existing } \\
\text { ecosystems and consider new } \\
\text { innovation opportunities that } \\
\text { may create new ecosystems } \\
\text { (and even render their } \\
\text { existing ecosystem obsolete) } \\
\text { (b) Assume 'junior partner' role } \\
\text { vis-à-vis relationships with } \\
\text { new ventures with radically } \\
\text { new ideas/technologies }\end{array}$ & $\begin{array}{l}\text { (a) Expedite the corporate } \\
\text { parent's learning and } \\
\text { catching up with industry } \\
\text { changes, after } \\
\text { independent ventures } \\
\text { have proven the viability } \\
\text { of new technologies or } \\
\text { products ventures } \\
\text { (b) Assemble resources and } \\
\text { skills that allow the } \\
\text { corporate parent to focus } \\
\text { on a unique market space }\end{array}$ & $\begin{array}{l}\text { (a) Boldly pursue opportunities } \\
\text { for new knowledge creation } \\
\text { in emergent areas that are } \\
\text { congruent with unique } \\
\text { internal assets, even in the } \\
\text { absence of hard evidence on } \\
\text { market potential } \\
\text { (b) Aggressively collaborate with } \\
\text { partners who possess } \\
\text { complementary assets/ } \\
\text { capabilities }\end{array}$ \\
\hline $\begin{array}{l}\text { MOD } \\
\text { Station }\end{array}$ & $\begin{array}{l}\text { (a) Adopt an open mindset to } \\
\text { spur knowledge } \\
\text { transformation (modding) on } \\
\text { proprietary products/ } \\
\text { technologies by diverse } \\
\text { partners } \\
\text { (b) Devise and offer new tools } \\
\text { and capabilities that } \\
\text { facilitate/speed up modding } \\
\text { (or transformation of } \\
\text { knowledge underlying } \\
\text { existing products) }\end{array}$ & $\begin{array}{l}\text { (a) Connect the parent with } \\
\text { changes in the } \\
\text { ecosystem, identify } \\
\text { promising applications, } \\
\text { negotiate access to } \\
\text { others' intellectual } \\
\text { property, and lead } \\
\text { marketing activities } \\
\text { (b) Explore ways to transform } \\
\text { dependence on other } \\
\text { participants in the } \\
\text { ecosystem in original } \\
\text { innovations created } \\
\text { within their operations }\end{array}$ & $\begin{array}{l}\text { (a) Identify opportunities to } \\
\text { modify/transform products/ } \\
\text { platforms of established } \\
\text { companies in ways that } \\
\text { leverage unique internal } \\
\text { assets } \\
\text { (b) Improvise/invent new } \\
\text { business models to } \\
\text { appropriate value from } \\
\text { modding }\end{array}$ \\
\hline
\end{tabular}


and other ecosystem participants create new products and services that either become part of the integrated solution when combined with the keystone player's offerings (e.g., Boeing and its partners developing the Dreamliner 787 airplane), or operate on top of the keystone player's primary product/ technology and add value as a complementary offering (e.g., Apple's iPhone and its partners' apps).

As suggested in Table 2, the primary challenge for the established company-typically, the keystone player-is to maintain the relevance of its innovation architecture/platform. In dynamic markets, the relevance of the value created by an ecosystem might diminish over time. This challenges the keystone players to question each and every business assumption that underlies their innovation architecture. When the market changes are continuous, it might only imply the need to make incremental changes in the architecture. However, sometimes the changes in the external market may be discontinuous and require the keystone player to reinvent its innovation architecture, as Microsoft did with its .NET initiative in 2002 to address the radical changes brought about by the Internet and service-oriented technologies to its Windows ecosystem. A key barrier to strategic thinking lies in the cognitive traps related to the dominant firm's existing architecture or platform. The ability of these companies to think beyond their existing platform boundaries and to draw them anew may be limited by the technological competencies they have developed over the years.

Some dominant firms create corporate ventures that explore new technological frontiers and help them build competencies in emerging technological fields while preserving their existing skills. These corporate ventures can also become vitally important relationships with other companies, both inside and outside their ecosystems. These relationships facilitate learning about emerging technologies, as well as upgrading their dominant parent's technological base.

Another aspect of strategic thinking relates to the keystone player's relationship with its ecosystem partners. This requires taking into consideration the benefits of all ecosystem partners before making decisions, even those that seemingly involve only the company's internal technologies or capabilities. Clearly, decisions related to the innovation platform imply a need to present a level/fair playing field to all partners so as to reinforce loyalty (Gawer \& Cusumano, 2002). Yet, even those decisions related to whether the ecosystem player should enter a new market space or invest in developing a new technology/expertise often have serious implications for its other partners and may send confusing signals to them. For example, when Google initiated a project to manufacture and market its own handheld phones as part of its Android ecosystem, its partners (e.g., Motorola) read this move as a signal that Google wanted to compete with them. Strategic thinking about the way to build and maintain partners' loyalty is essential for long-term success of the ecosystem.

For independent and corporate ventures, the key challenge is to identify new opportunities within the well-defined innovation space: one bounded by the keystone player's innovation architecture. Given the focus on existing knowledge, entrepreneurial activities often involve identifying and exploiting potential knowledge combinations that would lead to new value creation opportunities on the platform. This implies developing an in-depth understanding of customers' usage context/behavior in the ecosystem. It also requires combining such market knowledge with internal technological knowledge to identify untapped market opportunities that could be pursued; for example, unmet needs related to existing customers of the platform or extending the platform to a new set of customers. Entrepreneurial activities may also involve mapping a venture's other expertise/knowledge assets in the context of the ecosystem and identifying opportunities for deployment. This calls for making connections between the new venture's technological assets and those of the keystone player, or other ecosystem partners. Though some connections may be hidden or inconspicuous, they can lead to significant value creation opportunities, perhaps even redefining the nature of its relationship with the keystone player. Thus, entrepreneurial activities can be considered as 'market pull' (Are there other unmet customer needs in the ecosystem that we can target?), as well as 'technology push' (Are there opportunities to deploy our other assets in the ecosystem?). New ventures that pursue both of these entrepreneurial activities are likely to be more successful in the ecosystem.

\subsection{The Creative Bazaar Model}

In this ecosystem, a dominant firm shops for innovation in a global bazaar of new ideas, products, and technologies. It then uses its proprietary infrastructure to build on these ideas and commercialize them. Companies adopting this model use these different types of mechanisms to source new ideas and technologies from inventors with implications on innovation risk, reach, speed, and cost (Nambisan \& Sawhney, 2007b). Regardless of the approach employed, the dominant company offers its commercialization infrastructure-design capabilities, brands, capital, and distribution channels - for developing innovative ideas and getting the finished product/service to market. 
Here, a dominant firm's strategic thinking usually centers on the diversity of ideas that the company is interested in sourcing; the wider the net, the more diverse the ideas it can source. As we suggest in Table 2, established companies can use this as a mechanism to reimagine their products and markets; a bold approach toward external innovation sourcing can lead to radically new market opportunities for companies. However, this would also entail considerable rethinking of core asset target markets.

Strategic thinking by a keystone also involves redefining the openness of the firm's commercialization engine. The more closed that engine, the more difficult it will be to embrace external ideas and get them to the marketplace quickly and efficiently. However, opening up the commercialization engine may imply adopting a more transparent organizational culture, particularly at the middle management level where most interactions with external innovation partners occur and most project management decisions are made. There is also need for firms to adopt a longerterm perspective in sharing the innovation rewards (e.g., profits) with partners.

Entrepreneurial activities in new ventures usually evolve around seeking opportunities to marry innovative ideas with the commercialization opportunities offered by existing companies. To a great extent, this implies creating new dependencies for commercialization rather than pursuing opportunities alone. While entrepreneurs might be very passionate about their new ideas/technologies, partnerships with established companies may limit their power and influence in commercializing these ideas. Thus, sometimes the traditional, foundercentered new venture model has to be replaced with an established company-centered model in order to quickly and successfully commercialize the venture's discoveries and technologies.

Corporate ventures are sometimes created to facilitate commercialization activities by sidestepping corporate routines and bureaucracy. These ventures may also serve as partner 'relationship hubs' by simplifying access to corporate recognition and support, and further reinforcing loyalty to the dominant parent. A key point in entrepreneurial thinking within this ecosystem has to do with positioning the new venture as the preferred 'front-end of innovation' of a dominant player. This usually requires identifying areas for new knowledge creation, particularly in more emergent technology fields that can easily be aligned with the existing offerings of a dominant player. This knowledge creation strategy may be limiting to a certain extent, but can enhance the probability that such ideas are adopted by the dominant firm; for example, many small biotechnology companies have ensured rapid commercialization of their R\&D output by targeting areas of special interest to large pharma companies.

\subsection{The Jam Central Model}

This model involves a collection of independent entities, such as research centers, collaborating to envision and develop an innovation in an emergent or radically new field. The term 'jam' signifies the improvisational nature of innovation (i.e., the objectives and direction of the innovation tend to emerge organically from the collaboration) and the lack of centralized leadership in the ecosystem (i.e., there are no dominant companies and the governance responsibility is diffused among partners). In this type of ecosystem, new ventures play a primary role in creating new knowledge and ushering in new paradigms. In most instances, knowledge creation opportunities lie outside the purview of existing ecosystems. This new knowledge can create completely new ecosystems.

In considering knowledge development, a new venture may have to make decisions regarding R\&D and investments without the benefit of hard evidence related to commercialization opportunities or market risks. It may be evident that any success in commercializing new technology/knowledge is dependent on extensive collaboration with varied other partners working in the same or similar areas since most innovation efforts in emergent fields call for pulling together diverse, complex knowledge bases. The openness of interactions with such partners, potentially including other new ventures, may turn out to be a critical challenge: while knowledge must be shared and proprietary information revealed to advance commercialization opportunities, assets must also be protected.

Established companies often have limited understanding of the new knowledge or expertise generated by new ventures. This knowledge may also have the potential to redefine existing markets/industries or make their existing ecosystems obsolete. As a result, established companies face a key challenge in thinking beyond existing industry/market frameworks and imagining commercialization possibilities based on radically new knowledge. Oftentimes, this will require senior managers stepping outside their comfort zone to deal with new ventures from a more level playing field. Established companies may, indeed, end up being junior partners in these relationships because they lack unique contributions. For example, in open drug discovery initiatives, university research centers and small biotechnology firms can be key sources of innovation; the challenge for established companies is to manage their relationships with smaller partners who lead the innovation 
initiatives. An example of an established company that has successfully done so is IBM regarding its partnership with the open source software community (e.g., Linux). IBM largely played a supportive role in the open source community, offering its employees' time/effort for open source projects, and had limited say on project goals and activities. Over time, IBM's success in playing a 'minor partner' role has led to the company developing new businesses based on its involvement with the open source community; for instance, IBM's Linux-based business is a large component of the company's rapidly growing IT service division.

In this Jam Central ecosystem, fundamental discoveries and innovations are usually made by independent ventures. As established companies become better acquainted with these innovations, some of them develop a corporate venture that allows it to draw alongside industry development and capitalize on the parent firm's learning. These companies may be created or acquired from the pool of existing independent ventures. Once launched, these ventures join others to assemble different types and skills, and focus on building unique market space for their corporate owners.

\subsection{The MOD Station Model}

The term 'mod' originates from the PC-based video game industry where some companies allow their customers to create modifications, or mods, of existing games and distribute them to customers (Rosen, 2005). The MOD Station model follows such an approach, exploiting existing and often proprietary innovation architecture or product/platform (Nambisan \& Sawhney, 2007a). As such, companies focus on new markets or technological issues via a community of innovators-customers, scientists, experts, and the like-with established companies largely playing the role of catalyst by providing the innovation architecture for 'modding.'

As in the Jam Central model, independent new ventures typically provide much of the creative energy in this ecosystem, albeit within the parameters defined by an existing innovation architecture/ platform. The key entrepreneurial activity centers on exploring alternate applications for an existing product/technology in new and diverse markets, often accompanied by some level of knowledge creation related to recontextualizing the product. A key question for new ventures to address is: How can we modify or transform the knowledge underlying the existing offering (product/service) of the dominant firm in a way that leverages our internal capabilities and creates new value appropriation opportunities? Addressing this issue involves not only creating unique value-added modifications of the product/ platform, but also inventing or improvising unique business models that appropriate value from such efforts.

Corporate ventures play an important role in connecting their parent with changes in the ecosystem, identifying promising applications, negotiating access to others' intellectual property, and leading efforts intended to market and distribute products. Over time, these ventures need to explore ways to transform the dependencies on other participants in the ecosystem in original innovations created within their operations. For established companies, which typically offer the architecture/platform for modding, the key challenge lies in adopting an open mindset to promote entrepreneurial thinking and endure short-term losses in the pursuit of long-term market gains. The modding or knowledge transformation that new ventures undertake may enhance value for the established company's existing customers, increase the lifecycle of its existing products/technologies, and/or widen the reach of its products/technologies to new markets. Thus, while there may be considerable gains to be realized by the established company, these gains may only accrue in the long term. Moreover, they will have to be shared with other ecosystem partners; indeed, in many instances, short-term benefits may flow largely to the new ventures.

In addition to a long-term perspective in making decisions about the ecosystem, established companies need to adopt a more open approach. These companies often have to share proprietary information about their products/technologies with new ventures and other ecosystem partners. This open approach also means adopting new norms and values that facilitate such knowledge sharing with external partners. Further, established companies need to develop and provide access to tools and capabilities that make modding or knowledge transformation easier and cost-effective for their partners, thus attracting a wider range or diverse set of partners.

\section{Transformation in an ecosystem: Implications for managerial practice}

Understanding the linkage between thinking strategically and entrepreneurship sets the stage for exploring how managers exploit entrepreneurial activities for market leadership and value creation. A firm's ecosystem both inspires entrepreneurship and promotes strategic thinking. While there are things about the ecosystem that should be taken as 'givens,' there is considerable room for entrepreneurship in framing, revising, and transforming 
an ecosystem-or selected parts of it - for competitive advantage (Hanna, Rohm, \& Crittenden, 2011; lansiti \& Levien, 2004). Interestingly, the critical importance of connecting entrepreneurship and strategic thinking becomes evident when we consider different types of ecosystems.

Entrepreneurship can stimulate the emergence of growth and evolution by revising assumptions about boundaries and resources, which sets the stage for redefining the competitive arena. Entrepreneurship also requires the building of new relationships and linkages within an ecosystem, revising the dynamics of competition. In this context, it becomes a knowledge creating activity where the outcomes are thoughts, models, and new ways of organizing the firm's operations. Entrepreneurship is also useful in redefining the ecosystem where the firm offers its products, alerting it to the profound role of intangibles in competition. These changes alter the nature of the ecosystem, which in turn compels companies to change where and how to compete. Such dynamic relationships influence companies' strategic choices and how they position themselves in their markets (Adner \& Kapoor, 2010; Brush, 2008).

The discussion herein highlights the importance of boundary spanning activities. Even though individual entrepreneurs and companies might focus on building, organizing, and shaping their ecosystem, the knowledge and skills needed are available from multiple places: knowledge and innovation networks, clusters, research centers, et cetera. This makes it essential to connect and capture knowledge from these sources, a task that requires creativity and entrepreneurial orientation. It is also important to keep in mind that shaping or transforming an ecosystem implies different types of competitive dynamics will exist at various points in time. In turn, this calls for different mental and business models. As a result, strategy making and implementation thus become a constant managerial and entrepreneurial challenge, necessitating deliberate moves in some situations while emphasizing improvisation in other cases. Managers and entrepreneurs must understand that strategy extends beyond outsmarting the competition to novelty in thinking about the marketplace and how to deliver value for customers, taking into account the ecosystem in which competition unfolds. This requires constant adaptations and refinements in the company's strategic actions.

Being an integral part of an ecosystem has several important advantages: overcoming gaps in knowledge/skills; gaining access to critical resources, including financial capital; and building important relationships, or social capital, that firms can use in allying to commercialize new technologies. Further, the vision and the rules set by keystone companies within the ecosystem enable effective and profitable engagement with other partners and enhance complementarities among the partners (lansiti \& Levien, 2004; Moore, 1993, 1996; Shapiro \& Varian, 1999). These benefits can then serve to deter entry and encroachment on the domain held by existing companies. However, being part of an ecosystem requires constant adaptation, which adds layers of complexity to a firm's decision making. Also, retaining membership in an ecosystem demands compliance and conformity, which could lead to a lack of edginess, especially among new ventures. As a result, entrepreneurs and managers need to recognize the critical tradeoffs associated with ecosystem membership.

Business ecosystems offer their members opportunities to simultaneously collaborate and compete through radical and continuous innovation. Ecosystems vary considerably in their organization and business models, thereby influencing the strategic choices made by both established companies and new ventures. These choices require entrepreneurial activities that create, shape, and transform the competitive landscape. In turn, these changes ignite rivalry that stimulates innovation and alters the nature of the ecosystem itself. Companies that capitalize on this dynamic cycle among innovation, entrepreneurship, and strategic thinking in ecosystems are especially well positioned to succeed.

\section{References}

Abraham, S. (2005). Stretching strategic thinking. Strategy and Leadership, 33(5), 5-12.

Adner, R., \& Kapoor, R. (2010). Value creation in innovation ecosystems: How the structure of technological interdependence affects firm performance in new technology generations. Strategic Management Journal, 31(3), 306-333.

Andrew, C., Birkinshaw, J., Morrison, A., \& Van Basten Batenburg, R. (2003). The future of corporate venturing. MIT Sloan Management Review, 45(1), 30-37.

Brush, C. (2008). Pioneering strategies for entrepreneurial success. Business Horizons, 51(1), 21-27.

Busenitz, L. W., \& Barney, J. B. (1997). Biases and heuristics in strategic decision-making: Differences between entrepreneurs and managers in large organizations. Journal of Business Venturing, 12(1), 9-30.

Chussil, M. (2005). With all this intelligence, why don't we have better strategies? Journal of Business Strategy, 26(1), 26-33.

Dushnitsky, G. (2010). Entrepreneurial optimism in the market for technological inventions. Organization Science, 21(1), 150-167.

Gawer, A., \& Cusumano, M. (2002). Platform leadership. Cambridge, MA: Harvard Business School Press.

Hamel, G. (1996). Strategy as revolution. Harvard Business Review, 74(4), 69-82. 
Hamel, G., \& Prahalad, C. K. (1994). Competing for the future. Boston: Harvard Business School Press.

Hanna, R., Rohm, A., \& Crittenden, V. L. (2011). We're all connected: The power of the social media ecosystem. Business Horizons, 54(3), 265-273.

Iansiti, M., \& Levien, R. (2004). The keystone advantage: What the new dynamics of business ecosystems mean for strategy, innovation, and sustainability. Boston: Harvard Business School Press.

Isenberg, D. J. (2010). How to start an entrepreneurial revolution. Harvard Business Review, 88(6), 40-50.

Keil, T., McGrath, R. G., \& Tukiainen, T. (2009). Gems from the ashes: Capability creation and transformation in internal corporate venturing. Organization Science, 20(3), 601-620.

Liedtka, J. M. (1998). Linking strategic thinking with strategic planning. Strategy and Leadership, 26(4), 30-35.

Livingston, J. (2007). Founders at work: Stories of startups' early days. Berkeley, CA: Apress.

Mintzberg, H. (1987). Crafting strategy. Harvard Business Review, 65(4), 66-75.

Moore, J. F. (1993). Predators and prey: A new ecology of competition. Harvard Business Review, 71(3), 75-86.
Moore, J. F. (1996). The death of competition: Leadership and strategy in the age of business ecosystems. New York: Harper Business.

Nambisan, S., \& Sawhney, M. (2007a). The global brain: Your roadmap for innovating faster and smarter in a networked world. Upper Saddle River, NJ: Wharton School Publishing/ Pearson Press.

Nambisan, S., \& Sawhney, M. (2007b). A buyer's guide to the innovation bazaar. Harvard Business Review, 85(6), $109-118$.

Rosen, Z. (2005). Mod, man, and law: A reexamination of the law of computer game modifications. Chicago-Kent Journal of Intellectual Property, 4, 196-216.

Shapiro, C., \& Varian, H. (1999). Information rules: A strategic guide to the network economy. Boston: Harvard Business School Press.

Zahra, S. (2007). New venture strategies: Transforming caterpillars into butterflies. In S. C. Parker (Ed.), The life cycle of entrepreneurial ventures (pp. 39-79). New York: Springer.

Zahra, S., \& Nambisan, S. (2011). Entrepreneurship in global innovation networks. AMS Review, 1(1), 4-17. 